\title{
Study of the antimicrobial activities of Solanum indicum ssp. distichum (Schumach. and Thonning 1827) fruits ("gnangnan" berries) from a tropical humid zone (Côte d'Ivoire)
}

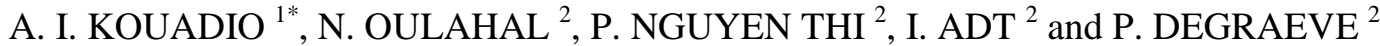 \\ ${ }^{1}$ Laboratoire de Biochimie et Sciences des Aliments, Unité de Formation et de Recherche (UFR) Biosciences, \\ Université de Cocody-Abidjan, 22 BP 582 Abidjan 22 (Côte d'Ivoire). Tel.: 00225 07250511, \\ Fax: 0022522444473 \\ ${ }^{2}$ Université Claude Bernard Lyon 1, Laboratoire de Recherche en Génie Industriel Alimentaire (LRGIA, EA \\ $\left.n^{\circ} 3733\right)$, Institut Universitaire de Technologie, Département de Génie Biologique, Technopole Alimentec - rue \\ Henri de Boissieu F-01000 Bourg-en-Bresse cedex 9, France, Tél. : 0033 04-74-47-21-40, \\ Fax: 0033 04.74.45.52.53 \\ E-mails: OULAHAL Nadia: nadia.oulahal@iut.univ-lyon1.fr,DEGRAEVE Pascal: \\ pascal.degraeve@adm.univ-lyon1.fr,NGUYENTHIPhuong:nguyenphuongtg@gmail.com, \\ ADT Isabelle: isabelle.adt@univ-lyon1.fr,irenekouadio@yahoo.fr \\ *Corresponding author, E-mail: irenekouadio@yahoo.fr
}

\begin{abstract}
The antibacterial activity of both aqueous and ethanolic extracts of Solanum indicum ssp. distichum (Schumach. and Thonning, 1872) fruits was investigated. These extracts were evaluated for antibacterial activity against two Gram positive (Listeria innocua LRGIA 01 and Staphylococcus aureus CNRZ3) and two Gram negative (Escherichia coli industrial strain and Pseudomonas aeruginosa ATCC 15742) strains. This evaluation was performed by following their growth by a spectrophotometric method in Brain Heart Infusion broth. L. innocua LRGIA01growth was completely inhibited by $0.04 \mathrm{~g} \cdot \mathrm{mL}^{-1}$ of aqueous extract of Solanum indicum berries, while a dose-dependent inhibition by 0.04 g.mL $\mathrm{mL}^{-1}$ and 0.1 g.mL $\mathrm{mL}^{-1}$ ethanolic extracts was observed. Conversely, the inhibitory activity of ethanolic extract on P. aeruginosa ATCC 15742 growth, was higher than that of aqueous extract. E. coli industrial strain and $S$. aureus CNRZ 3 growth were inhibited by 0.1 mg.mL $\mathrm{mL}^{-1}$ ethanolic extract but not by $0.04 \mathrm{mg} \cdot \mathrm{mL}^{-1}$ ethanolic or aqueous extracts. These results suggest that different classes of compounds are likely responsible for the antibacterial activities. The high inhibitory activity of aqueous and ethanolic extracts on L. іпnосиa LRGIA01 and P. aeruginosa ATCC 15742 strains, respectively calls for further studies to identify the antibacterial compounds present in Solanum indicum berries and their mechanisms of action.
\end{abstract}

(C) 2011 International Formulae Group. All rights reserved.

Keywords: Solanum indicum, fruits, aqueous extract, ethanolic extract, antimicrobial activity.

\section{INTRODUCTION}

The emerging of pathogenic bacteria resistant to antibiotics and their distribution in human populations are a major problem in infectious diseases (Jumpeau et al., 1994). 
Therefore, the search for new substances to overcome the growing human problems of drugs resistance in bacteria is worthy. Nature has provided abundant plant wealth for all living creatures, which possess medicinal virtues (Bhatti et al. 1998). The important values of some plants have long been published but a large number of them remain are yet unexplored. So there is a necessity to explore their uses and to conduct pharmacognostic and pharmacological studies to ascertain their therapeutic properties (Baquar, 1989). In West Africa, about 350 species have been listed and described by Baumer (1995). Among these plants, Solanum indicum ssp. distichum (Schumach. and Thonning, 1827) which is a wild plant widespread in tropical and temperate zones. It belongs to the family of Solanaceae and the genus Solanum, with more than 1,700 species. This species is an erect plant of 0.30 to 1.5 meters in height. The leaves are ovate, 3.5 to 15 centimeters long, and 2.5 to 8 centimeters wide. The leaves in the branchlets are much smaller. The unripe fruit is green while, the color of the ripe fruit varies from yellow to red. They are rounded; about 0.8 to 1.5 centimeters in diameter.

These fruits are berries used for culinary purposes in many parts of Africa where they are used as nutritious vegetables as they contain appreciable amounts of starch, calcium, vitamin A, ascorbic acid and phosphate (Bahgat et al., 2008). In addition to components mentioned above, these berries have been shown to contain polyphenols (N'Dri et al., 2010) and steroidal glycosides (Ripperger \& Himmelreich, 1994; Honbu et al., 2002).

Therapeutically used are seeds, roots, leaves and berries. They are described as useful in asthma, dry cough, and chronic febrile afflictions and also in dysuria. The berry is useful in leucoderma, pruritis and bronchistis. Moreover, it has been claimed in folk medicine to have an antihypertensive effect (Rubaiyaho, 1995). It has also been used in Chinese folk medicine as antiinflammatory and wound-healing agents; as an analgesic, and for the treatment of rhinitis, cough, and breast cancer (Syu et al., 2001). In Thailand, the berries are available in the markets. These fruits are used as vegetables and as essential ingredients in anticarcinogens.

In West Africa, these berries are used in most of the cases as an additive for the treatment of some diseases. Indeed, in Nigeria, they are used as a laxative and digestive. In Côte d'Ivoire, berries soup is used as an additive in the treatment of malaria. All these uses are not based on scientific studies but rather on empirical practices. Therefore, investigations on their medicinal properties and antimicrobial properties are needed.

It has been noted that in an area such as Côte d'Ivoire, where climatic conditions are favorable to the infection of vegetables products by microorganisms and insects, the berries of $S$. indicum whatever their maturity stage, seem to resist to all infections, while for the other species belonging to the same genus, fruits are infected. Thus, this research work was carried out in order to identify the antimicrobial properties of $S$. indicum berries for a contribution to the search for new substances, on one part to overcome the growing human problems of drugs resistance in microorganisms and on the other part, to use these new substances for food protection.

\section{MATERIALS AND METHODS Materials Biological material}

In this study, ripe berries of Solanum indicum ssp. distichum (Schumach. and Thonning, 1827) were used. These berries were collected from rural zones of the central part of Côte d'Ivoire. Four food-borne bacterial strains (Escherichia coli industrial strain, Listeria innocua LRGIA 01, 
Staphylococcus aureus CNRZ3 and Pseudomonas aeruginosa ATCC 15742) were also used. The choice of these strains is due to the fact that, three of them (Escherichia coli, Staphylococcus aureus and Pseudomonas aeruginosa) are frequently isolated in food and feed in Ivory Coast and the other one (Listeria innocua) also more found in frozen products sold on Ivorian markets.

\section{Media and chemicals}

The bacterial culture medium used in this study was the Brain Heart Infusion (BHI) broth. A standard solution of bacteriocin (Nisin of $2400 \mathrm{UI} / \mathrm{ml}$ ) was also used.

\section{Methods}

\section{Fruit extracts preparation}

Ripe berries of Solanum indicum were grounded and $30 \mathrm{~g}$ of the obtained homogenate were added to $150 \mathrm{~mL}$ of ethanol $70 \%(\mathrm{v} / \mathrm{v})$. The mixture was boiled in water bath at $80{ }^{\circ} \mathrm{C}$ for $1 \mathrm{~h}$ under gentle stirring. The resulting mixture was centrifuged at $1500 \mathrm{rpm}$ for $5 \mathrm{~min}$. The supernatant was then filtered through Whatman paper and the filtrate was lyophilized. The lyophilisate obtained was dissolved in BHI broth in order to obtain final concentration at $0.04 \mathrm{~g} / \mathrm{mL}$ and $0.1 \mathrm{~g} / \mathrm{mL}$ (final volume: $20 \mathrm{ml}$ ). The resulting solutions were sterilized by filtration onto $0.2 \mu \mathrm{m}$ cutoff membranes. The aqueous extraction was also made under similar conditions.

The use of ethanol and water for extraction of berries was due to the fact that, the molecules responsible of the antibacterial properties will be used in products for consumption.

\section{Preparation of the tested strains}

A quantity of $1 \mathrm{ml}$ of each strain previously stored in glycerol $15 \%$ at $-20{ }^{\circ} \mathrm{C}$ was thawed in $9 \mathrm{ml}$ of $\mathrm{BHI}$. The obtained suspension was firstly incubated at $30^{\circ} \mathrm{C}$ for 8 hours. In a second step, $1 \mathrm{ml}$ each of the microbial suspension obtained after 8 hours of incubation was put in $9 \mathrm{ml}$ of BHI. The whole was incubated at $30{ }^{\circ} \mathrm{C}$ overnight. The absorbance of this second culture was measured with a spectrophotometer at 630 $\mathrm{nm}$. The optical density was adjusted at 0.6 by diluting (1/10) and the microbial suspension was cultured.

Afterwards, $1 \mathrm{ml}$ of each second crop was put in $9 \mathrm{ml}$ of BHI. This microbial suspension obtained was used for cultivation in micro-plate.

\section{Bioscreen analysis}

The solution of BHI, the Nisin solution of $2400 \mathrm{IU} / \mathrm{ml}$ and the extracts solutions (ethanol extracts and aqueous extracts) of 300 $\mu 1$ each were placed in separate wells of the micro-plate without any strain. Each solution was placed in at least three wells of the microplate.

In a second step, the microbial strains tested (30 $\mu \mathrm{l}$ each) are cultured in other separate wells of the micro-plate contained the different solutions (270 $\mu \mathrm{l}$ each) mentioned above. These cultures were made in at least three wells of the micro-plate. The seeded plate was cultured in the Bioscreen apparatus at $30{ }^{\circ} \mathrm{C}$ and at a wavelength of $600 \mathrm{~nm}$ for 26 hours. The measurement of the optical density expressing microbial growth was taken every $15 \mathrm{~min}$.

\section{Statistical analysis}

The statistical analysis of data was made by Analysis of Variance (ANOVA) using 5\% level of significance. The statistical package used was GraphPad Prism 5.0. Tukey's Multiple Comparison test was used to identify these differences.

\section{RESULTS}

The results obtained show that $L$. innocua LRGIA01 growth was completely inhibited by 0.04 g.mL $\mathrm{mL}^{-1}$ of aqueous extract of 
Solanum indicum berries (Fig $1 \mathrm{~d}$ ), while a dose-dependent inhibition by 0.04 g. $\mathrm{mL}^{-1}$ and 0.1 g.mL $\mathrm{mL}^{-1}$ ethanolic extract was observed (Table 3). The inhibitory activity of ethanolic extract on $P$. aeruginosa ATCC 15742 growth, strain naturally resistant to multiple antibiotics, was higher than that of aqueous extract (Fig. 1 a). It means that, depending on the type of extraction solvent, different classes of compounds responsible for the antibacterial activities are extracted. At $0.04 \mathrm{~g} / \mathrm{ml}$, the ethanolic extract has a significant inhibitory effect on the growth of $P$. aeruginosa ATCC $15742(\mathrm{P}<0.05)$, while for the three other strains tested (Staphylococcus aureus CNRZ3,
Escherichia coli industrial strain and Listeria innocua LRGIA 01), no significant inhibitory effect was observed $(\mathrm{P}>0.05)$. However, at 0.1 g. $\mathrm{mL}^{-1}$ of ethanolic extract, all the strains tested were inhibited (Fig. 1 a, b, c, d). As $L$. innocua LRGIA 01, Pseudomonas aeruginosa ATCC 15742 was significantly inhibited at 0.04 g. $\mathrm{mL}^{-1}$ aqueous extract $(\mathrm{P}<0.05)$, while, for Escherichia coli industrial strain and Staphylococcus aureus CNRZ3 no significant inhibitor effect on their activities was observed (Table $4, \mathrm{P}>0.05$ ). It means that, the sensitivity of the two Gram negative and the two Gram positive strains tested appeared very different.

Table 1: Inhibitory effect of ethanol extract at $0.04 \mathrm{~g} / \mathrm{ml}$ on Escherichia coli industrial strain, Listeria innocua LRGIA 01, Staphylococcus aureus CNRZ3 and Pseudomonas aeruginosa ATCC 15742.

\begin{tabular}{|c|c|c|c|c|c|}
\hline & Mean Diff. & $\mathbf{q}$ & $\begin{array}{c}\text { Significant } \\
\mathbf{P}<0.05\end{array}$ & Summary & $95 \%$ CI of diff \\
\hline $\begin{array}{l}\text { BHI + Pseudo vs } \\
\text { Ethanol extract at } \\
0.04 \mathrm{~g} / \mathrm{ml}+ \\
\text { Pseudo }\end{array}$ & 0.6342 & 13.88 & Yes & $* * *$ & 0.4357 to 0.8327 \\
\hline $\begin{array}{l}\text { BHI + Staph vs } \\
\text { Ethanol extract } \\
0.04 \mathrm{~g} / \mathrm{ml}+\text { Staph }\end{array}$ & 0.05127 & 1.122 & No & ns & -0.1472 to 0.2498 \\
\hline $\begin{array}{l}\text { BHI + E. coli vs } \\
\text { Ethanol extract at } \\
0.04 \mathrm{~g} / \mathrm{ml}+\mathrm{E} . \text { coli }\end{array}$ & 0.05008 & 1.096 & No & $\mathrm{ns}$ & -0.1484 to 0.2486 \\
\hline $\begin{array}{l}\text { BHI + Listeria vs } \\
\text { Ethanol extract at } \\
0.04 \mathrm{~g} / \mathrm{ml} \\
+ \text { Listeria }\end{array}$ & 0.1267 & 2.773 & No & ns & $\begin{array}{c}-0.07181 \text { to } \\
0.3252\end{array}$ \\
\hline $\begin{array}{l}\text { Tukey's Multiple Com } \\
\text { ns: not significant } \\
\text { Pseudo: Pseudomonas } \\
\text { Staph: Staphylococcus } \\
\text { E. coli: Escherichia co } \\
\text { Listeria: Listeria inno }\end{array}$ & $\begin{array}{l}\text { rison test } \\
\text { eruginosa ATCC } \\
\text { ureus } \text { CNRZ3 } \\
\text { industrial strain } \\
\text { a LRGIA } 01\end{array}$ & 5742 & & & \\
\hline
\end{tabular}


A. I. KOUADIO et al. / Int. J. Biol. Chem. Sci. 5(3): 1190-1200, 2011

Table 2: Column statistics (minimum values, median values, maximum values, mean, standard deviation, standard error).

\begin{tabular}{|c|c|c|c|c|c|c|c|c|}
\hline & $\begin{array}{c}\text { BHI + } \\
\text { Pseudo }\end{array}$ & $\begin{array}{c}\text { Ethanol } \\
\text { extract at } \\
\text { 0.04g/ml + } \\
\text { Pseudo } \\
\end{array}$ & BHI + Staph & $\begin{array}{c}\text { Ethanol extract } \\
\text { at } 0.04 \mathrm{~g} / \mathrm{ml}+ \\
\text { Staph }\end{array}$ & $\begin{array}{l}\text { BHI + } \\
\text { E. coli }\end{array}$ & $\begin{array}{c}\text { Ethanol } \\
\text { extract at } \\
0.04 \mathrm{~g} / \mathrm{ml}+\mathrm{E} \text {. } \\
\text { coli } \\
\end{array}$ & BHI + Listeria & $\begin{array}{c}\text { Ethanol extract } \\
\text { at } 0.04 \mathrm{~g} / \mathrm{ml}+ \\
\text { Listeria }\end{array}$ \\
\hline Number of values & 104 & 104 & 104 & 104 & 104 & 104 & 104 & 104 \\
\hline Minimum & 0,0949 & $-0,0748$ & 0,3092 & 0,0325 & 0,2529 & 0,0672 & 0,0779 & $-0,0298$ \\
\hline $25 \%$ Percentile & 1,073 & 0,9014 & 1,534 & 1,358 & 1,512 & 1,333 & 1,532 & 1,294 \\
\hline Median & 1,788 & 1,010 & 1,757 & 1,737 & 1,745 & 1,674 & 1,791 & 1,641 \\
\hline $75 \%$ Percentile & 1,956 & 1,094 & 1,811 & 1,896 & 1,804 & 1,890 & 1,839 & 1,825 \\
\hline Maximum & 2,005 & 1,138 & 1,835 & 2,018 & 1,829 & 2,034 & 1,869 & 1,925 \\
\hline Mean & 1,499 & 0,8652 & 1,590 & 1,539 & 1,574 & 1,524 & 1,567 & 1,440 \\
\hline Std. Deviation & 0,5776 & 0,3619 & 0,3650 & 0,4986 & $\mathbf{0 , 3 7 8 6}$ & $\mathbf{0 , 4 8 3 9}$ & $\mathbf{0 , 4 7 3 2}$ & $\mathbf{0 , 5 3 7 9}$ \\
\hline Std. Error & 0,05664 & 0,03548 & $\mathbf{0 , 0 3 5 7 9}$ & 0,04889 & $\mathbf{0 , 0 3 7 1 2}$ & 0,04745 & 0,04641 & 0,05274 \\
\hline Lower $95 \%$ CI & 1,387 & 0,7948 & 1,519 & 1,442 & 1,500 & 1,430 & 1,475 & 1,336 \\
\hline Upper $95 \%$ CI & 1,612 & 0,9355 & 1,661 & 1,636 & 1,647 & 1,618 & 1,659 & 1,545 \\
\hline
\end{tabular}

Pseudo: Pseudomonas aeruginosa ATCC 15742

Staph: Staphylococcus aureus CNRZ3

E. coli: Escherichia coli industrial strain, Listeria: Listeria innocua LRGIA 01 
Table 3: Dose-dependent effect.

\begin{tabular}{|c|c|c|c|c|c|}
\hline & Mean Diff. & $\mathbf{q}$ & Significant $\mathrm{P}<0.05$ & Summary & $95 \%$ CI of diff. \\
\hline BHI + Pseudo vs Ethanol extract at $0.1 \mathrm{~g} / \mathrm{ml}+$ Pseudo & 1.223 & 31.02 & Yes & $* * *$ & 1.039 to 1.408 \\
\hline BHI + Staph vs Ethanol extract at $0.1 \mathrm{~g} / \mathrm{ml}+$ Staph & 0.9808 & 24.87 & Yes & $* * *$ & 0.7963 to 1.165 \\
\hline BHI + E. coli vs Ethanol extract at $0.1 \mathrm{~g} / \mathrm{ml}+$ E. coli & 0.9888 & 25.07 & Yes & $* * *$ & 0.8043 to 1.173 \\
\hline BHI + Listeria vs Ethanol extract at $0.1 \mathrm{~g} / \mathrm{ml}+$ Listeria & 1.204 & 30.53 & Yes & $* * *$ & 1.019 to 1.388 \\
\hline
\end{tabular}
Tukey's Multiple Comparison Test.

Table 4: Inhibitor effect of the aqueous extract at $0.04 \mathrm{~g} / \mathrm{ml}$ on activity of Escherichia coli industrial strain, Listeria innocua LRGIA 01, Staphylococcus aureus CNRZ3 and Pseudomonas aeruginosa ATCC 15742.

\begin{tabular}{|c|c|c|c|c|c|}
\hline & Mean Diff. & $\mathbf{q}$ & Significant? $P<0.05 ?$ & Summary & $95 \%$ CI of diff \\
\hline BHI + Pseudo vs Aqueous extract at $0.04 \mathrm{~g} / \mathrm{ml}+$ Pseudo & 0.2763 & 7.006 & Yes & $* * *$ & 0.09180 to 0.4608 \\
\hline BHI + Staph vs Aqueous extract $0.04 \mathrm{~g} / \mathrm{ml}+$ Staph & -0.06863 & 1.740 & No & ns & -0.2531 to 0.1159 \\
\hline BHI + E. coli vs Aqueous extract at $0.04 \mathrm{~g} / \mathrm{ml}+$ E. coli & 0.01518 & 0.3851 & No & ns & -0.1693 to 0.1997 \\
\hline $\mathrm{BHI}+$ Listeria vs Aqueous extract at $0.04 \mathrm{~g} / \mathrm{ml}+$ Listeria & 1.579 & 40,05 & Yes & $* * *$ & 1.395 to 1.764 \\
\hline
\end{tabular}

Pseudo: Pseudomonas aeruginosa ATCC 15742, Staph: Staphylococcus aureus CNRZ3, E. coli: Escherichia coli industrial strain, Listeria: Listeria innocua LRGIA 01. 


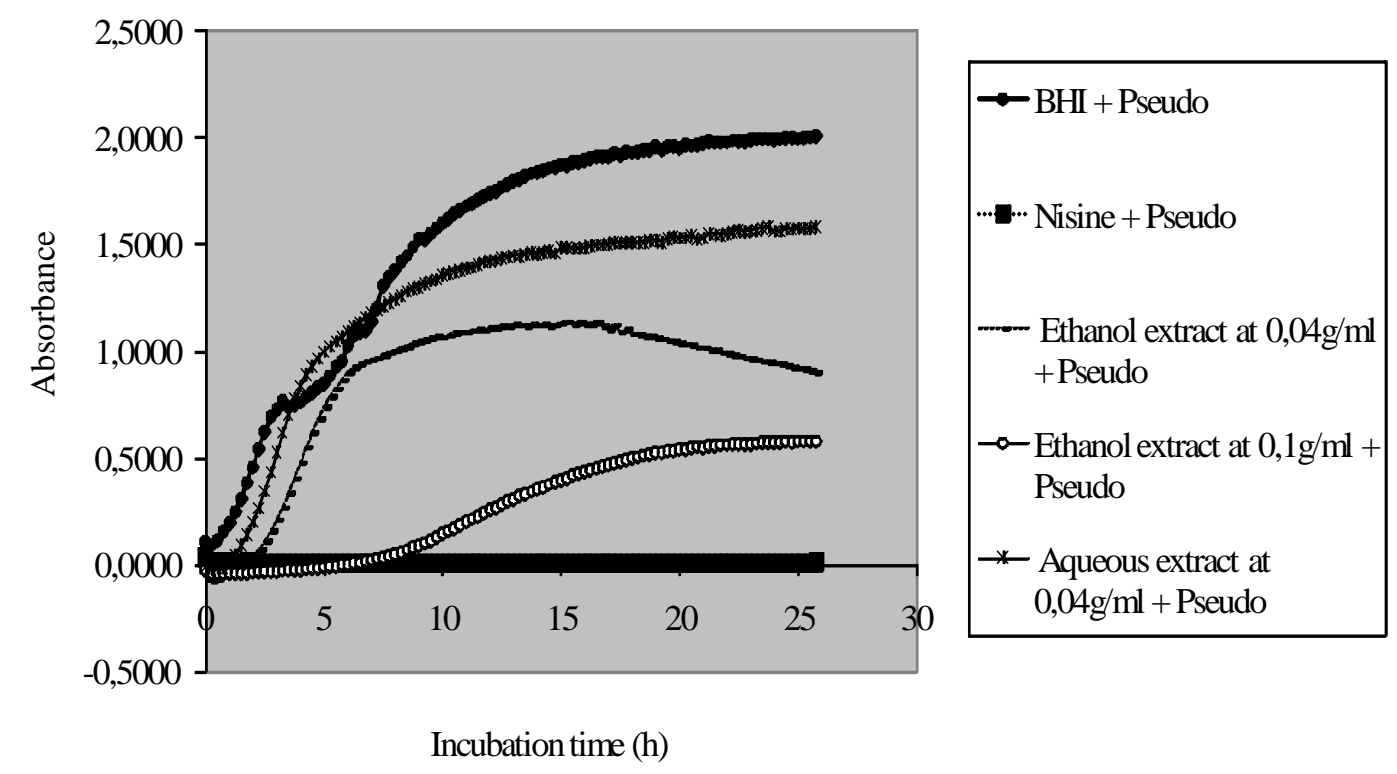

Figure 1a: Effect of Solanum indicum berries extracts on the activity of Pseudomonas aeruginosa ATCC 15742.

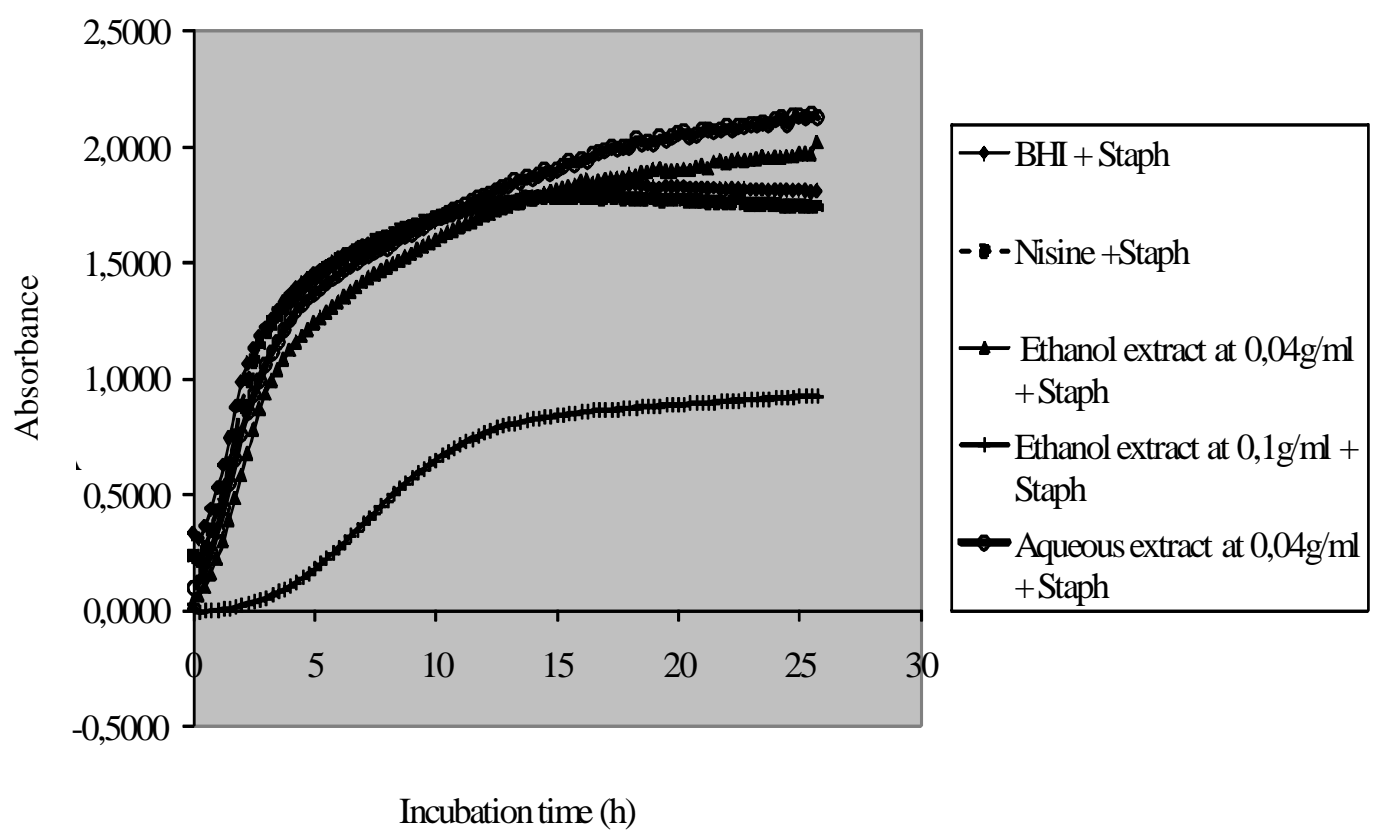

Figure 1b: Effect of Solanum indicum berries extracts on the activity of Staphylococcus aureus CRNZ3. 


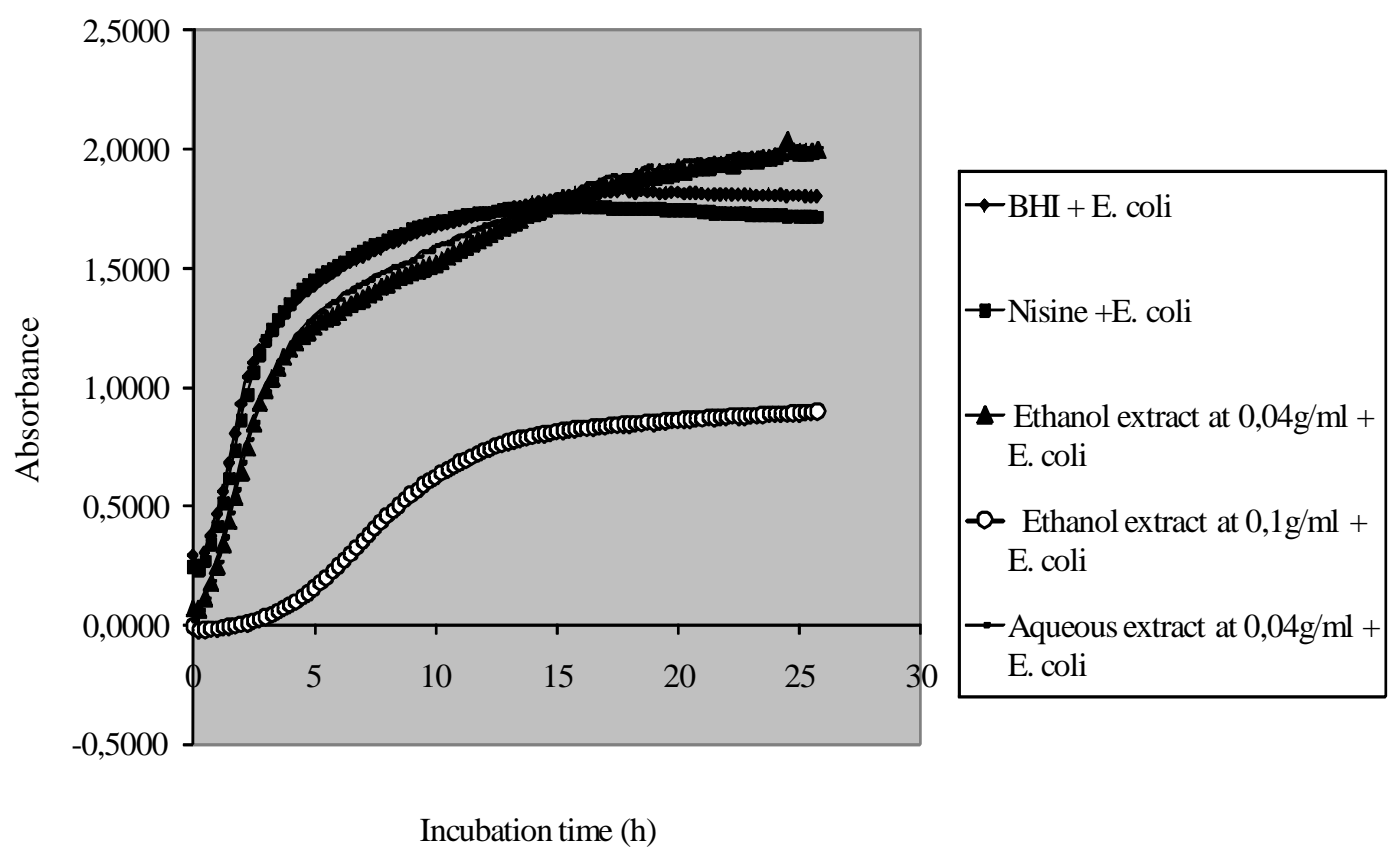

Figure 1c: Effect of Solanum indicum berries extracts on the activity of Escherichia coli industrial strain.

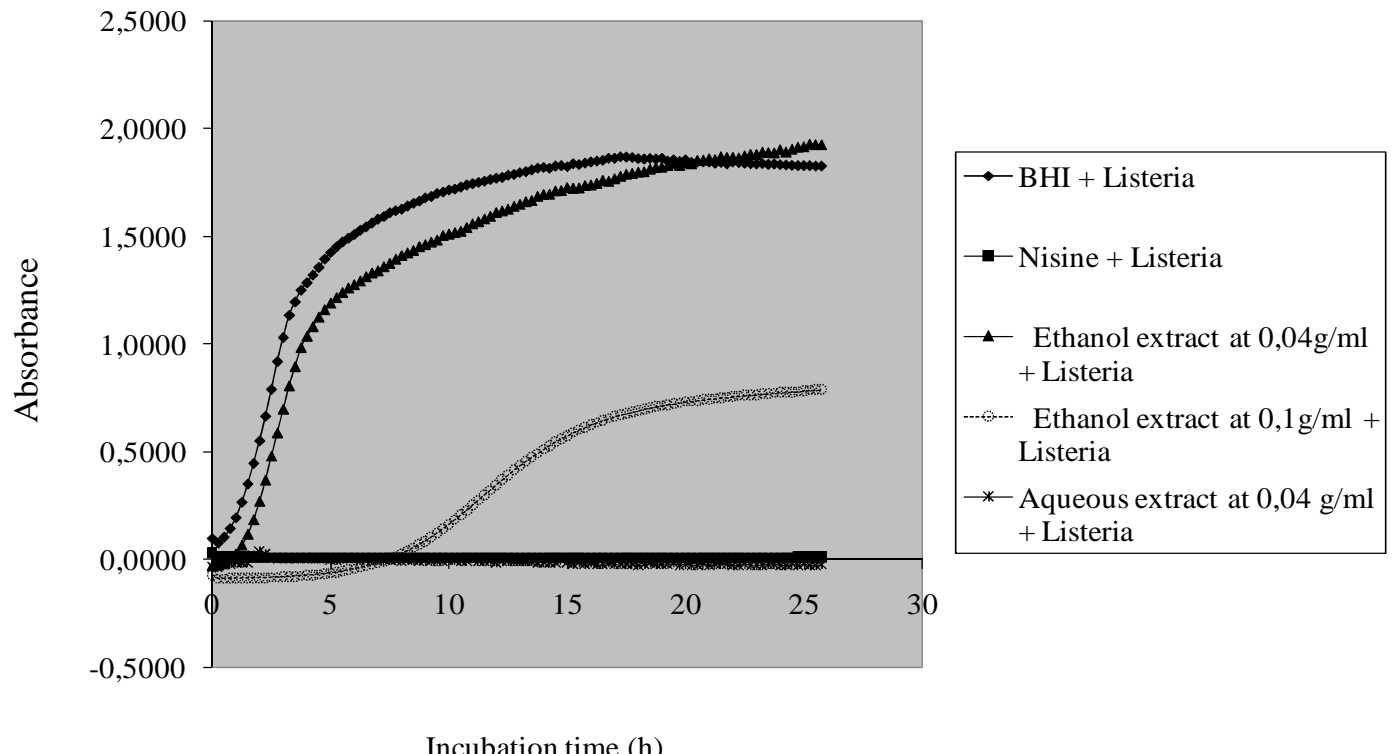

Figure 1d: Effect of Solanum indicum berries extracts on the activity of Listeria innocua LRGIA 01. 


\section{DISCUSSION}

In this study, the ethanol extract of $S$. indicum berries exhibited a significant inhibition on the growth of Escherichia coli industrial strain, Listeria innocua LRGIA 01, Staphylococcus aureus CNRZ3 and Pseudomonas aeruginosa ATCC 15742 with a dose-dependent manner.

Indeed, with the ethanol extract at 0.04 g. $\mathrm{mL}^{-1}$, a significant inhibitory effect was observed only on Pseudomonas aeruginosa activity, while, for the ethanol extract reaching 0.1 g. $\mathrm{mL}^{-1}$, a significant inhibitor effect on the activities of the four strains tested was observed. The aqueous extract showed an inhibition on the activities of Pseudomonas aeruginosa ATCC 15742 and Listeria innocua LRGIA 01. Thus, S. indicum berries possess anti-bacterial properties. It was noted that the sensitivity of the two Gram negative and the two Gram positive strains tested appeared very different.

A previous study has also shown an inhibitory effect of ethanol extract of $S$. indicum leaves on Staphylococcus aureus and Escherichia coli (Srividya et al., 2009). However, the aqueous extract tested by these authors showed any anti-microbial activities towards the tested strains. Therefore, concerning the anti-microbial properties, the effectiveness of the berries is remarkable than those of the leaves. In our study, it is noted that, whatever the type of extract (ethanol extract or aqueous extract) and whatever its concentration, a significant inhibition of Pseudomonas aeruginosa activity was observed. However, the inhibitory activity of ethanolic extracts on $P$. aeruginosa ATCC 15742 growth, strain naturally resistant to multiple antibiotics, was higher than that of aqueous extract. It means that, depending on the type of extraction solvent, different classes of compounds responsible for the antibacterial activities are extracted.

In previous studies, it has been noted that, Pseudomonas aeruginosa is a clinically significant pathogen characterized by intrinsic resistance to a number of antimicrobial agents. Indeed, Pseudomonas species are opportunistic naturally resistant to multiple antibiotics such as penicillin group A (ampicillin and derivatives), cephalosporins of first and second generation, chloramphenicol and trimethoprim. To this natural resistant, is added an acquired resistance (Lombardi et al., 2002).

They are also resistant to antibiotics such as ticarcillin, piperacillin, to third generation cephalosporins, fluoroquinolones (ofloxacin, ciprofloxacin) and aminoglycosides (gentamicin) (Nordmann, 2003). This species is an invasive Gramnegative bacteria pathogen, responsible for a wide range of clinical manifestations, including pneumonia, urinary tract infection, and bacteremia, in the immunocompetent patient.

In the immune compromised host, Pseudomonas aeruginosa may behave as an opportunistic pathogen, causing severe invasive diseases, and represents one of the most severe nosocomial pathogens (GrisaruSoen et al., 2000; Fergie et al., 1994; Castagnola et al., 2008; Simon et al., 2008; Chatzinikolaou et al., 2000). Its multiresistance also represents an increasing problem (Garnica et al., 2009; Mesaros et al., 2007). The low permeability of its cell wall, together with mutations leading to antibioticresistance via overexpression of efflux pumps, decreased expression of porine, or mutations in quinolone targets, make Pseudomonas aeruginosa a pathogen with high propensity to become multi-resistant to antibiotic therapy. Multi-resistant strains may be responsible for nosocomial outbreaks (Mesaros et al., 2007; Gaynes and Edwards, 2005). Therefore, the use of $S$. indicum berries extracts with such remarkably effectiveness concerning inhibition of activity of Pseudomonas aeruginosa and accessible by everyone as medicinal product to overcome the growing 
human problems of drugs resistance in this species could be a solution.

\section{Conclusion}

The result of this investigation revealed that Solanum indicum berries possess significant antimicrobial activities due to its inhibitory effect (at $0.1 \mathrm{~g} . \mathrm{mL}^{-1}$ of ethanolic extract) on the activities of four strains tested (E. coli industrial strain, L. innocua LRGIA 01, S. aureus CNRZ3 and $P$. aeruginosa ATCC 15742). This species more inhibited by berries extracts is a causative agent of opportunistic infections, especially among hospitalized patients most vulnerable. Indeed, $P$. aeruginosa infection is a serious problem in patients hospitalized with cancer, cystic fibrosis, HIV positive and burns. Thus, the use of such natural product with a remarkably effectiveness is a hope. This property establishes the use of Solanum indicum berries extracts as a traditional antibacterial medicine.

Further research is to be carried out to make fractions and purify the extract, in order to find out the fractions and molecules responsible for the anti-bacterial activities observed.

\section{REFERENCES}

Bahgat A, Abdel-Aziz H, Raafat M, Mahdy A, El-Khatib AS, Ismail A, Khayyal MT. 2008. Solanum indicum ssp. distichum extract is effective against L-NAMEinduced hypertension in rats. Fundam Clin Pharmacol., 22(6): 693-9.

Baquar SR. 1989. Medicinal and Poisonous Plants of Pakistan. Printas : Karachi; 9596, 184-185, 248-249, 337-440.

Baumer M. 1995. Arbres, Arbustes et Arbrisseaux Nourriciers en Afrique Occidentale. Enda Tiers-Monde : Dakar; 260 .

Bhatti GR, Qureshi R, Shah M. 1998. Ethnobotany of Calotropis procera with especial reference to the people of Nara Desert. Scientific Sindh, 5: 13-22.
Castagnola E, Bagnasco F, Faraci M, Caviglia I, Caruso S, Cappelli B, Moroni C, Morreale G, Timitilli A, Tripodi G, Lanino E, Haupt R. 2008. Incidence of bacteremias and invasive mycoses in children undergoing allogeneic hematopoietic stem cell transplantation: a single center experience. Bone Marrow Transpl., 41(4): 339-347.

Fergie JE, Shema SJ, Lott L, Crawford R, Patrick CC. 1994. Pseudomonas aeruginosa bacteremia in immunocompromised children: analysis of factors associated with a poor outcome. Clin Infect Dis., 18(3): 390-394.

Garnica M, Maiolino A, Nucci M. 2009. Factors associated with bacteremia due to multidrug-resistant Gram-negative bacilli in hematopoietic stem cell transplant recipients. Braz. J. Med. Biol. Res., 42(3): 289-293.

Gaynes R, Edwards JR. 2005. National Nosocomial Infections Surveillance System. Overview of nosocomial infections caused by gram-negative bacilli. Clin Infect Dis., 41(6): 848-854.

Grisaru-Soen G, Lerner-Geva L, Keller N, Berger H, Passwell JH, Barzilai A. 2000. Pseudomonas aeruginosa bacteremia in children: analysis of trends in prevalence, antibiotic resistance and prognostic factors. Pediatr. Infect. Dis. J., 19(10): 959-996.

Honbu T, Ikeda T, Zhu XH, Yoshihara O, Okawa M, Nafady AM, Nohara T. 2002. New steroidal glycosides from the fruits of Solanum anguivi. J. Nat. Prod., 65: 1918-1920.

Jumpeau AM, Vessieres - Scavizzi MR. 1994. Evolution de la résistance bactérienne aux antibiotiques E.M.C. Maladies infectieuses 8-006-0-10.

Lombardi G, Luzzaro F, Docquier JD, Riccio ML, Perilli M, Coli A, Amicosante G, Rossolini GM, Toniolo A. 2002. Nosocomial infections caused by 
multidrug-resistant isolates of Pseudomonas putida producing VIM-1 metallo- $\beta$-lactamase. J. Clin. Microbiol., 40(11): 4051-4055.

Mesaros N, Nordmann P, Plésiat P, RousselDelvallez, M, Van Eldere J, Glupczynski Y, Van Laethem Y, Jacobs T. 2007. Pseudomonas aeruginosa: resistance and therapeutic options at the turn of the new millennium. Clin Microbiol Infect., 13(6): 560-78.

N'Dir D, Calani L, Mazzeo T, Scazzina F, Rinaldi M, Del Rio D, Pellegrini N, Brighenti F. 2010. Effect of different maturity stages on antioxidant content of Ivorian Gnagnan (Solanum indicum L.) berries. Molecules, 15: 7125-7138.

Nordmann N. 2003. Mécanismes de résistance aux bêtalactamines de Pseudomonas aeruginosa. Ann. Fr. Anesthésie Réanim., 22(6): 527-530.

Ripperger H, Himmelreich U. 1994. Anguivine and isoanguivine, steroid alkaloid glycosides from Solanum anguivi. Phytochemistry, 37: 1725-1727.

Rubaihayo EB, 1995. Conservation and use of traditional vegetables in Uganda. Proc. IPGRI Int. Workshop Genetic Resources Traditional Vegetables Africa
Conservation Use, Nairobi, Kenya, 29-31 August, 1995.

Simon A, Ammann RA, Bode U, Fleischhack G, Wenchel HM, Schwamborn D, Gravou C, Schlegel PG, Rutkowski S, Dannenberg C, Körholz D, Laws HJ, Kramer MH. 2008. Nosocomial infections in pediatric cancer patients: results of a prospective surveillance study from 7 University hospitals in Germany and Switzerland. BMC Infect. Dis., 70 E-Pub May 23.

Srividya AR, Arunkumar A, Cherian B, Maheshwari V, Piramanayagam S, Senthoorpandi V. 2009. Pharmacognostic, phytochemical and anti-microbial studies of Solanum indicum leaves. Ancient Sci. Life, 29(1): 3-5.

Syu W, Don M, Lee G, Sun C. 2001. Cytotoxic and novel compounds from Solanum indicum. J. Nat. Prod., 64 : 1232-1233. 